\title{
1. The trade and human rights debate: Introduction to an interdisciplinary analysis
}

\section{Jeff Waincymer}

\section{INTRODUCTION AND METHODOLOGY}

There has been a growing debate about the compatibility between the international trade regime and the promotion of universal human rights. In this volume we seek to analyse this relationship. ${ }^{1}$ There are two related aspects of

1 This volume builds upon earlier work in the field including F M Abbott et al. (eds) International Trade and Human Rights: Foundations and Conceptual Issues (University of Michigan Press, Michigan, 2006); Padideh Ala'i, 'Global Trade Issues in the New Millennium: A Human Rights Critique of the WTO: Some Preliminary Observations' (2001) 33 George Washington International Law Review 537; Philip Alston, 'Linking Trade and Human Rights' (1980) 23 German Yearbook of International Law 126; Thomas Cottier, 'Trade and Human Rights, a Relationship to Discover' (2002) 5 Journal of International Economic Law 111; Thomas Cottier et al. (eds) Human Rights and International Trade (Oxford University Press, Oxford, 2005); Frank J Garcia, 'The Global Market and Human Rights: Trading Away the Human Rights Principle' (1999) 25 Brooklyn Journal of International Law 51; Frank J Garcia, Trade, Inequality and Justice: Toward a Liberal Theory of Just Trade (Transnational Publishers, New York, 2003); S Leader, 'Human Rights and International Trade' in P F J Macrory et al. (eds) The World Trade Organisation: Legal, Economic and Political Analysis (Springer, New York, 2005) 664; H Lim, 'Trade and Human Rights: What's At Issue?' (2001) 35 Journal of World Trade 275; Ernst-Ulrich Petersmann, 'From Negative to Positive Integration in the WTO: Time for Mainstreaming Human Rights into WTO Law?' (2000) 37 Common Market Law Review 1363; Stephen J Powell, 'The Place of Human Rights Law in World Trade Organization Rules' (2004) 16 Florida Journal of International Law 219; Friedl Weiss et al. (eds) International Economic Law with a Human Face (Kluwer Law International, The Hague, 1998); Lorand Bartels, 'Trade and Human Rights' in D Bethlehem et al. (eds) Oxford Handbook of International Trade (Oxford University Press, Oxford, 2008) Ch 21; Wolfgang Benedek, 'The World Trade Organisation and Human Rights' in W Benedek et al. (eds) Economic Globalisation and Human Rights (Cambridge University Press, Cambridge, 2007) 143; Andrew Lang, 'Rethinking Trade and Human Rights' (2007) 15 Tulane Journal of International and Comparative Law 335. 
this endeavour. The first is to consider whether the World Trade Organisation ('WTO') unduly interferes with the promotion of human rights as a result of the promises governments make to each other through WTO treaty provisions. Some of these provisions are seen to directly or indirectly limit governmental ability to regulate for the benefit of human rights. Key areas where this debate arises involve government measures in relation to health and the environment and the potential use of trade sanctions as a counter to human rights abuses. These measures are sometimes threatened with challenge through the WTO dispute settlement system on the basis that they might impact negatively upon the rights of international traders. The second is to consider whether the WTO ought to do more in order to promote the attainment of universal human rights. If it can legitimately be argued that the ultimate goal of all governance systems is to promote human rights, then any institution is failing in its obligations if it does not prioritize that goal.

At the extreme, some critics argue that globalization in general and the WTO in particular allow for markets to improperly take primacy over international human rights law; ${ }^{2}$ that the WTO is unfair, opaque and undemocratic and that certain of the WTO's specific norms undermine the rights to sustainable development, health, education, knowledge, culture and labour rights. ${ }^{3}$

The purpose of this chapter is to set the scene for this debate and situate the specific chapters that follow. It seeks to outline some of the key methodological issues that face anyone attempting to answer these questions. How should we approach the analysis of the topic? What intellectual disciplines and data sets are relevant? What are the proper parameters for any useful study? Can we keep our study within manageable limits or will that detract from the validity of any postulated conclusions? What are the difficulties in establishing causal links between actions and outcomes and what other problems of proof arise when we seek to provide persuasive conclusions? After outlining the challenges facing any attempt at a comprehensive analysis, this volume then deals with a selection of the more significant topics.

These questions show how wide-ranging the debate could prove to be and why it would be impossible to resolve all relevant questions through any one intellectual discipline alone. ${ }^{4}$ For example, as to the possible interference with

2 Marjorie Cohn, 'The World Trade Organisation: Elevating Property Interests Above Human Rights' (2001) 29 Georgia Journal of International and Comparative Law 427.

3 See, for example, Anne-Christine Habbard and Marie Guiraud, 'The World Trade Organisation and Human Rights' (FIDH Position Paper, 1999) FIDH, www.fidh.org/IMG/pdf/omc320A.pdf at 14 December 2008.

4 A similar interdisciplinary approach has been adopted with respect to human rights analysis per se: see Michael Freeman, Human Rights: An Interdisciplinary 
human rights by the WTO, this will overlap with challenges as to the role of globalization per se and the suggested value of market-based mechanisms. Such a challenge can be divided into two further sub-questions. The first is whether trade liberalization as encouraged by the WTO is inherently antithetical to the development goals of human rights. Conversely, can it be argued that the promotion of economic efficiency is a useful precondition to the ultimate advancement of human rights via increased world welfare? From an economics perspective, we might wish to consider the extent to which the WTO does in fact promote efficiency and the extent of any positive correlation between increased efficiency and world welfare. Alternatively, what merit is there in modern critiques of neo-classical economic postulates? ${ }^{5}$

Secondly, even if it is hypothesized that efficiency can have a useful instrumental value for human rights, are there other conflicts between the two regimes? For example, even if trade liberalization is desirable from an efficiency perspective at least, does it nonetheless interfere with some human rights by shifting resources from less efficient, but still deserving people, to more efficient traders who accumulate wealth but do not show any responsibility for the welfare of those who may have lost out in the process? Such economic questions then naturally segue into philosophical ones. If some groups in society are winners and others losers as a result of trade liberalization, we might ask by what philosophical construct will we determine whether such an outcome is fair or not? To the extent that it is not, what redistribution obligations arise as a result? Can we ameliorate the problem by adopting redistribution processes that remove any a priori unfairness flowing from a liberal trading regime? What do different philosophical schools of thought say about short- and long-term compensatory obligations or about hierarchies of norms?

A consideration of distributional processes as well as outcomes also asks us to consider the functions and limits of political and legal institutions and hence the fields of political science and political economy. For example, what does

Approach (Policy Press, Cambridge, 2002). While the WTO has been the focus of a number of studies from other disciplines (for example Bernard M Hoekman and Michel M Kostecki, The Political Economy of the World Trading System from GATT to WTO (Oxford University Press, Oxford, 1995); K Bagwell and R W Staiger, The Economics of the World Trading System (MIT Press, Cambridge, 2002); Jeffrey L Dunoff and Joel P Trachtman, 'Economic Analysis of International Law' (1999) 24 Yale Journal of International Law 1; P F J Macrory et al. (eds) The World Trade Organisation: Legal, Economic and Political Analysis (Springer, New York, 2005), and while the leading WTO scholars draw on a range of disciplines (see generally the works of Robert Howse and Ernst-Ulrich Petersmann, contributors to this volume) there have been few significant interdisciplinary studies of the WTO.

5 For a critical legal studies perspective see Roberto Unger, Free Trade Reimagined: The World Division of Labour and the Method of Economics (Princeton University Press, Princeton, 2007). 
political science have to say about the ability of legal mechanisms to prevent vested interests capturing international institutions and interfere unduly with the hoped for fair and efficient outcomes from the activities of the institutions concerned? Is there merit in the neo-realist critique of international law? At the extreme this would place serious doubts on the ability of international trade and human rights lawyers to create legal mechanisms that could meaningfully enhance outcomes within each field or enhance the relationship between the two fields. Alternatively, if some organizational structures are more likely to be successful than others, how do the international trade and human rights regimes measure up? Would significant structural changes in either enhance their individual utility and their compatibility?

These examples show how many of the sub-themes involve complex interdisciplinary questions about which there can be legitimate debate. Because of the central place of these interdisciplinary questions in the overall theme of this volume, a number of the chapters seek to provide insights from the key fields of philosophy, economics, political science and sociology. In this way we hope to advance the growing debate about the optimal relationship between trade and human rights, defuse the overly polarized nature of that debate and in turn, avoid what a former director general of the WTO, Renato Ruggiero, described as a 'dialogue of the deaf'. 6

We have separated the key interdisciplinary areas, but inevitably there is overlap and interdependence as is shown in most of the contributions. For example, a utilitarian philosophical perspective would more naturally be accepting of liberal trade policies and would be less inclined to accept the notion of universal and equal human rights than would be the case with a social contractarian perspective.

It should also be understood that other intellectual disciplines not directly covered in this volume can be brought into the analysis. Both philosophy and economics bring us to issues of cognitive psychology. Psychological perspectives are one element of the critique of the assumptions of rationality underpinning welfare economics. Psychological perspectives can also be drawn into philosophical discourse. For example, Patrick Emerton's chapter looks at the degree to which more fortunate countries owe duties to those less fortunate. ${ }^{7}$ He considers the work of the philosopher John Rawls, who used a thought experiment to argue for a particular model of a liberal social contract. Rawls suggested that imaginary risk-averse subjects operating behind a veil of ignorance would support a political system which evaluates the justice in their

6 Renato Ruggiero, 'A Shared Responsibility: Global Policy Coherence for Our Global Age' (Address to the Conference on 'Globalization as a Challenge for German Business', Bonn, 9 December 1997).

7 See Chapter 6. 
society through a consideration of how the worst off in that society are treated. ${ }^{8}$ Cognitive psychologists would see their field having much to say about such risk-averse proclivities. Psychological perspectives might also help us to better understand why there are demands for cultural diversity even in instances where this comes at the expense of economic efficiency. This is dealt with in the chapter by Hélène Ruiz Fabri on trade and culture. ${ }^{9}$ Anthropologists have indirectly considered related issues by analysing the phenomenon of globalization. ${ }^{10}$

While we have adopted a strong interdisciplinary focus and have sought contributions from a range of scholars, our dominant focus is to consider the role of law and legal institutions in providing an optimized relationship between the WTO and human rights. In one sense, that debate is simply a subset of broader governance issues. What are the rights of each individual in a just society, howsoever that is to be defined? How are these rights agreed upon? How should decisions be made, particularly where some trade-off is required between different legitimate aspirations? What regulatory mechanisms will optimize the attainment of those rights? This aspect of the debate is obviously not unique to the question of the WTO and human rights. It occurs at national and regional levels. As to the latter, the debate has been conducted at a particularly sophisticated level in the context of the European Union. The EU is always a useful model for scholarly analysis in relation to our theme as the Treaty of Rome contains key GATT-type norms and there has been a rich jurisprudence and literature on the integration of trade and social welfare goals. ${ }^{11}$

Where the WTO is concerned, it is an aspect of the global governance problem. Global governance is inevitably more challenging and more naturally a

8 John Rawls, A Theory of Justice (Harvard University Press, Cambridge, 1971).

See Chapter 8 .

10 See for example L Sklair, 'Competing Conceptions of Globalization' in C Chase-Dunn and S J Babones (eds) Global Social Change: Historical and Comparative Perspectives (Johns Hopkins University Press, Baltimore, 2006) 59; D Held and A McGrew, Globalization/Anti-Globalization (2002); Immanuel Wallerstein, The Modern World System (Academic Press, New York, 1974-1989) .

11 Treaty establishing the European Economic Community, opened for signature 25 March 1957, 298 UNTS 11 (entered into force 1 January 1958) ('Treaty of Rome'). See Joseph Weiler, The EU, the WTO, and the NAFTA: Towards a Common Law of International Trade? (Oxford University Press/Academy of European Law, Florence, 2000); Joseph Weiler and Marlene Wind, European Constitutionalism Beyond the State (Cambridge University Press, Cambridge, 2003); Ernst-Ulrich Petersmann, 'Time for a United Nations "Global Compact" for Integrating Human Rights into the Law of Worldwide Organisations: Lessons from European Integration' (2002) 13 European Journal of International Law 621. 
field for second-best analysis and solutions than is the still-complex governance debate at any national level. We can never expect the same level of efficiency and coordination between international political systems as we could expect within any individual domestic government system. Yet many of the most pressing problems can only be dealt with at the international level. In this sense, our concern with the WTO and human rights might indeed be seen as just one part of the 'linkage' or 'trade and ...' debate as described in much recent WTO related literature. ${ }^{12}$ This debate looks at the way the trade regime can be properly integrated with other policy fields such as health, environment and technology, the latter including knowledge and technology transfer. It will also cover questions as to the optimal international regulatory structure to deal with linkage questions. This issue has been raised in the influential study by Martti Koskenniemi as to the fragmentation of international law and legal institutions. $^{13}$

The next key methodological concern is to determine what combination of inductive, deductive and empirical analysis is most appropriate to the question we have posed. There is also the question of the breadth of the field of analysis and the appropriate data to be considered. While our central question relates to issues of governance, there is a need to separate the WTO debate from other fields of analysis. The WTO debate should not be confused with such broader questions as the role of globalization per se although there may be a significant overlap. ${ }^{14}$ Furthermore, while the WTO is a central element of international economic law, its role and responsibilities should not be confused with other aspects of the system, as for example the International Monetary Fund and the adverse impact its lending practices have been argued to have on human rights in least developed countries. ${ }^{15}$

The debate can remain at the general level or might look at particular features of the system, both substantive and procedural. As to substantive

12 Symposium, 'The Boundaries of the WTO' (2002) 96 American Journal of International Law 1.

13 Martti Koskenniemi, Fragmentation of International Law: Difficulties Arising from the Diversification and Expansion of International Law: Report of the Study Group of the International Law Commission, UN Doc A/CN.4/L.682 (13 April 2006).

14 See for example Eleanor M Fox, 'Globalisation and Human Rights: Looking out for the Welfare of the Worst Off' (2002) 35 New York University Journal of International Law and Politics 201; Mary Robinson, 'Shaping Globalisation: The Role of Human Rights' (2003) 19 American University International Law Review 1.

15 See for example A Brysk (ed.) Globalisation and Human Rights (University of California Press, Berkeley, 2002); S Skolgy, Human Rights Obligations of the World Bank and the International Monetary Fund (Cavendish Publishing Limited, London, 2001). 
norms, we would naturally look at those rules which are most affected by the WTO and human rights interface, rules such as those pertaining to health, in particular the Agreement on Sanitary and Phytosanitary Measures ('SPS'), 16 the Agreement on Trade Related Intellectual Property Rights ('TRIPS') 17 and similar agreements as to their human rights implications. This includes examination of both the express and implied linkage of trade liberalization and human rights and the hierarchy of express norms. The SPS Agreement is touched upon in a range of chapters in this volume. ${ }^{18}$

There might even be a preliminary question as to whether we can meaningfully debate the topic at the general level without looking at specific instances, for example, which human right is arguably being affected; is it accepted as such a right; what trade liberalization norm impacts upon it; how should any conflict between those two specific norms be resolved and why? Such an approach would be unlikely to lead to uniform conclusions about the relationship between the regimes. For example, most commentators have found a justifiable basis for criticizing the very inclusion of the TRIPS regime within the WTO and its impact upon human rights concerns such as the AIDS crisis in Africa. ${ }^{19}$ Other sectoral issues might conversely raise broader policy debates. A key question in the field of permitted health regulation is the degree of scientific certainty that is required. This involves principles of risk management theory and the relevance or otherwise of precautionary principles under international law. Here there can at least be legitimate debate about optimal models and trade-offs. ${ }^{20}$

16 Marrakesh Agreement Establishing the WTO, opened for signature 15 April 1994, 1867 UNTS 3 (entered into force 1 January 1995) Annex 1A (Agreement on Sanitary and Phytosanitary Measures).

17 Marrakesh Agreement Establishing the WTO, opened for signature 15 April 1994, 1867 UNTS 3 (entered into force 1 January 1995) Annex 1C (Agreement on Trade-Related Aspects of Intellectual Property Rights).

18 See, respectively, Chapters 2, 10, 11, and 12.

19 Sarah Joseph, 'Pharmaceutical Corporations and Access to Drugs: The "Fourth Wave" of Corporate Human Rights Scrutiny' (2003) 25 Human Rights Quarterly 425.

20 See, for example, Vern R Walker, 'Keeping the WTO from Becoming the "World Trans-Science Organization": Scientific Uncertainty, Science Policy and Fact Finding in the Growth Hormones Dispute' (1998) 31 Cornell International Law Journal 251; Jeffrey Atik and David A Wirth, 'Science and International Trade Third Generation Scholarship' (2003) 26 Boston College International and Comparative Law Review 171; Alan O Sykes, 'Exploring the Need for International Harmonisation: Domestic Regulation, Sovereignty and Scientific Evidence Requirements: A Pessimistic View' (2002) 3 Chicago Journal of International Law 353. 
Alternatively, one might ask, as Thomas Cottier has, whether a comprehensive view and theory is needed, rather than a sector-by-sector analysis of conflicting norms. ${ }^{21}$

A consideration of governance from a lawyer's perspective could segment the analysis in other ways, in particular by looking at the WTO and human rights systems from a legislative, executive $e^{22}$ and adjudicative perspective $e^{23}$ as well as through analysing the value of the core substantive norms themselves.

After a both top-down conceptual analysis and an inductive analysis of past experiences we might then ask whether there are legitimacy challenges to the WTO regime in the absence of an express link and priority ordering with human rights norms and if so why?

\section{WHAT IS THE WTO, WHAT ARE HUMAN RIGHTS AND WHAT DO EACH AIM TO DO?}

In order to properly understand the relationship between the regimes of international trade and human rights we need to understand what each aims to do and why its goals are independently worthy. What can and should the two regimes do for each other? Do they conflict in any way and if so, how should this be avoided or resolved?

Where the WTO is concerned, it is best understood as a legal response to protectionist behaviour by domestic governments. ${ }^{24}$ History shows that protectionism is likely to reduce world welfare and constitute a barrier to harmonious and cooperative intergovernmental relationships. Political economy shows why even governments that believe in the value of free trade are likely to follow their own self-interest and pander to protectionist interests,

21 Thomas Cottier, 'A Theory of Direct Effect in Global Law' in A von Bogdany et al. (eds) European Integration and International Coordination: Studies in Transnational Economic Law in Honour of Claus-Dieter Ehlermann (Kluwer Law International, The Hague, 2002) 99, 113.

22 For example see Daniel Esty, 'Good Governance at the World Trade Organisation: Building a Foundation of Administrative Law' (2007) 10 Journal of International Economic Law 509.

23 Gabrielle Marceau, 'WTO Dispute Settlement and Human Rights' (2002) 13 European Journal of International Law 753. Chantal Thomas, in Chapter 10, compares legislative and adjudicative responses and they might apply in the trade and labour interface.

24 For an analysis of the development of the World Trade Regime see Joost Pauwelyn, 'The Transformation of World Trade' (2005-2006) 104 Michigan Law Review 1. 
absent any regulatory or other mechanisms that discourage them from doing so. ${ }^{25}$

In responding to the problem of protectionism via intergovernmental legal constraints, the core feature of the WTO is the requirement of nondiscrimination by governments through their international trade rules. This entails both non-discrimination as to the treatment of goods and services emanating from different foreign supplier countries ${ }^{26}$ and also between local and foreign producers, ${ }^{27}$ save in the latter case for the permitted form of protection, namely, a tariff on imported goods. ${ }^{28}$ Thus the aim of the WTO is to limit protection to transparent and non-discriminatory taxes. It supports this goal through the proscription of bans on international trade and through norms that limit other non-tariff barriers to trade. ${ }^{29}$

Those who are less familiar with the international trade regime need to understand that the WTO rules do not require free trade or even demand trade liberalization, although the organization supports the latter by providing a negotiating forum in which countries may lower and then bind their tariff levels on a non-discriminatory basis. ${ }^{30}$ Importantly, however, there is no legal obligation to reduce these permitted tariffs. Nevertheless, the system encourages such reductions and in that sense is based on the economic theory of comparative advantage, which suggests that nations should concentrate their productive endeavors in those fields where they have a comparative advantage as against other supplier countries. They should then trade the surpluses from such specialization to obtain the goods and services where they do not have sufficient comparative advantage. Even if one country is more efficient in all sectors than another, if the first concentrates on what it does best and lets the

25 Arye L Hillman, The Political Economy of Protection (Harwood Academic Publishers, Switzerland, 1989) 2.

26 Marrakesh Agreement Establishing the WTO, opened for signature 15 April 1994, 1867 UNTS 3 (entered into force 1 January 1995) Annex 1A (General Agreement on Tariffs and Trade 1994) ('GATT 1994') Article I; Marrakesh Agreement Establishing the WTO, opened for signature 15 April 1994, 1867 UNTS 3 (entered into force 1 January 1995) Annex 1B (General Agreement on Trade in Services) ('GATS') Article II.

27 Article III GATT 1994; Article XVII GATS.

28 The GATS Agreement allows countries to designate which service sectors they wish to bring under non-discriminatory norms. These commitments are found within each country's Schedules to the Agreement.

29 Where goods are concerned, this occurs through Article XI GATT 1994. Again, services are somewhat different as WTO members only promise to open services markets where they expressly include those markets in positive schedules to the GATS Agreement.

30 Commitments as to bound tariffs are contained in Article II GATT 1994 and the individual Member's tariff schedules. 
other concentrate on the things it is closer to in efficiency, then both will be better off through trade. This is crucial from a development perspective as the theory postulates that even the poorest and least efficient country will have some comparative advantage. Thus the very existence of the WTO is justified by the argued benefits of trade liberalization, but has no direct liberalization obligations.

From its inception, the GATT system contained exceptions to the above obligations, which in part covered human rights concerns, although the exceptions do not utilize that concept expressly. The best example is Article XX GATT 1994 which among other things, allows for exceptions in fields such as health and the environment. These are not blanket exceptions and depend upon certain factors being established. The best-known examples are exceptions for measures 'necessary to protect human, animal or plant life or health'; ${ }^{31}$ and measures 'relating to the conservation of exhaustible natural resources'. ${ }^{32}$ Much of WTO legal analysis looks at adjudication of disputes in this arena.

Some well-publicized disputes in the health and environment arena tend to hold centre stage in the WTO and human rights scholarship to date. ${ }^{33}$ In terms of our project, the first methodological concern with these disputes is that the sample for analysis is particularly small. Here it is necessary to not only consider the outcomes in individual cases but also the nature of international adjudication and its strengths and weaknesses. If the outcomes are thought to be problematic, is it the fault of the rules or the adjudicatory processes or both?

One recurring problem in any field of international legal regulation is that the rules are often last-minute compromises made between countries with very divergent interests. Hence they are often poorly drafted and pose greater strain on adjudicatory processes. Nevertheless, a key aim of WTO regulation must be to ensure a proper distinction on a case-by-case basis between acceptable and unacceptable behaviour, with enough bright line certainty in the rules and their interpretation to decrease transaction costs and decrease incentives to protectionism, while still supporting desirable social policies.

\footnotetext{
31 Article XX(b) GATT 1994.

32 Article XX(g) GATT 1994.
}

33 See for example United States - Import Prohibition of Certain Shrimp and Shrimp Products, WTO Doc WT/DS58/AB/R (12 October 1998) (Report of the Appellate Body) ('Shrimp/Turtle'); European Communities - Measures Concerning Meat and Meat Products (Hormones), WTO Doc WT/DS26/AB/R; WT/DS48/AB/R (13 February 1998) (Report of the Appellate Body); European Communities Measures Affecting Asbestos and Products Containing Asbestos, WTO Doc WT/DS135/R (18 September 2000) (Report of the Panel); European Communities Measures Affecting the Approval and Marketing of Biotech Products, WTO Docs WT/DS291/R, WT/DS292/R, WT/DS293/R (29 September 2006) (Panel Report). 
Cases at the interface of the trade and human rights debate pose particular problems for adjudicators. Even if one started with the hypothesis that human rights are more important than trade liberalization benefits, (to the extent that they might be incompatible), the WTO system still has a real need to prevent protectionism. This is accepted as a legitimate concern by many of our commentators, including those arguing for a strong human rights focus. ${ }^{34} \mathrm{~A}$ particular problem would be where protectionist measures are inappropriately labelled as human rights measures simply to protect them from successful challenge. There are real examples of protectionist measures whose construction is based on a strict literal interpretation of WTO rules. Examples beyond the human rights arena include the variable levy of the European Union's Common Agricultural Policy and Australia's tariff quota system used in the past in the fields of textiles, clothing and footwear. Neither formally imposes bans, but impose tariffs in some circumstances at such high levels as to be tantamount to the same thing from a commercial perspective. This kind of governmental behaviour in the face of international legal commitments has to be a legitimate concern even for those who wish to increase the opportunity of States to regulate for human rights purposes. The need to prevent abusive protectionist practices does not trump that right or mean that human rights proponents need to guarantee that their policy prescriptions can block any potential protectionist misuse of human rights provisions, but the issue is a key part of the regulatory challenge. On the other hand, there is a need to consider whether protectionism itself can ever be a means by which to promote human rights.

From a legal perspective, we might at some stage ask if there are any tensions to be found within the rules or their application and interpretation. This is a theme taken up in the chapter by Robert Howse and Ruti Teitel. ${ }^{35}$ While this chapter covers a broad range of topics, the authors look at the possible conflicts between the WTO's norms and the rights to work, health and food emanating from the International Covenant on Economic, Social and Cultural Rights ('ICESCR') ${ }^{36}$ to determine whether there is a conflict in the rules or in the jurisprudence pertaining to them. The authors conclude that there is no inherent conflict in this aspect of the rules and that sensible WTO jurisprudence can avoid any potential conflict. ${ }^{37}$ The authors also conclude that any

34 See, for example, Chapters 2, 10, 11, and 12.

35 See Chapter 2.

36 Opened for signature 16 December 1966, 999 UNTS 3 (entered into force 3 January 1976).

37 This is to be contrasted with Frank J Garcia who argues that there are fundamental incompatibilities between the two regimes as currently constituted: Frank J Garcia, 'The Universal Declaration of Human Rights and the Challenge of Global Markets: Trading Away the Human Rights Principle' (1999) 25 Brooklyn Journal of 
potential problems arise primarily from the traditional isolation of the trade regime's culture from human rights perspectives. They suggest that WTO adjudication that gives sufficient attention to human rights norms should not lead to conflict, although they do identify instances where adjudicatory behaviour did not meet their recommended approach. This question is also taken up in the chapter by Caroline Foster with respect to the relationship between trade rules and governmental entitlements to provide optimal health and safety policies. The chapter is less sanguine on this issue of potential conflict and the sensibilities of the jurisprudence, although its critical conclusions are a result of the distinct thesis that in the context of scientific uncertainty, a WTO Member should be able to defend health and safety measures on the basis that the population does not want to adopt the particular risk. Such a call to consider subjective preferences in the context of this interdisciplinary volume raises questions as to the relevance of such preferences for the identification of human rights norms, in particular in helping to set proper parameters for civil and political rights as well as the right to health. ${ }^{38}$ That in turn raises important questions as to the foundations of a liberal democracy, an issue taken up in Patrick Emerton's chapter in relation to the political theories of John Rawls. ${ }^{39}$ Sarah Joseph and Chantal Thomas, in their respective contributions, include an analysis of the jurisprudence in this arena as part of an examination of the legislative processes. Sarah Joseph looks at it in the context of analysing alleged democratic deficit, and Chantal Thomas looks at it in the context of alternative reform models in the trade and labour arena. ${ }^{40}$ Our ultimate conclusions about the relationship between the two legal regimes may depend on an inductive analysis of a range of such sector specific papers, ${ }^{41}$ coupled with a concern for such interdisciplinary challenges.

International Law 51. For a broader analysis of the compatibility of WTO norms with other international law norms, see Joost Pauwelyn, Conflict of Norms in Public International Law: How WTO Law Relates to Other Rules of International Law (Cambridge University Press, London, 2003).

38 See Robert Howse, 'Democracy, Science and Free Trade: Risk Regulation on Trial at the World Trade Organisation' (2000) 98 Michigan Law Review 2329, who points to the view that deliberative democracy is not only about representation of the will of the people but also moral justification for the policies selected. Moral perspectives also entail the possibility of giving concern to the interests of foreign citizens although this again calls into question the Pogge/Rawls debate discussed in Chapter 6.

39 Chapter 6.

40 See, respectively, Chapters 12 and 10.

41 Examples include Lorand Bartels, 'Article XX of GATT and the Problem of Extraterritorial Jurisdiction: The Case of Trade Measures for the Protection of Human Rights' (2002) 36 Journal of World Trade 353; Robert Howse and E Tuerk, 'The WTO Impact on International Regulations: A Case Study of the Canada-EC Asbestos Dispute' in G De Burca and J Scott (eds) The EU and the WTO: Legal and Constitutional Issues (Hart Publishing, Oxford, 2001). 
These papers at least show that there are differing views as to how much reliance can be placed on adjudicators to get the balance right. Some of our contributors advocate strengthening the legal relationship between trade and human rights norms. For example, Ernst-Ulrich Petersmann ${ }^{42}$ concludes with a declaration that he successfully proposed for adoption by the International Law Association as to the need for WTO adjudication to give sufficient deference to international human rights law. Shervin Majlessi, ${ }^{43}$ in his contribution, supports a broad adoption of the WTO Director-General's Geneva Consensus, which calls for concern for the negative impacts of trade liberalization being taken into account at the same time as trade opening is advocated.

\section{THE NATURE OF HUMAN RIGHTS}

The previous section sought to identify a relatively narrow aim of the WTO system. In turn, one cannot say whether the WTO unduly interferes with human rights without knowing what is comprised in that concept. There is a need to accept that the ambit, nature and level of legal obligations with regard to many human rights are contentious, particularly where economic rights are concerned. In part, this is caused by a lack of consensus as to the sources of human rights.

One can take a positivist approach and look to the treaty documents that establish such rights, plus customary law norms of the same nature, or instead approach the question from a broader philosophical perspective. Where the first approach is concerned, key human rights sources are the references to human rights in the Preamble and Articles 1, 55 and 56 of the Charter of the United Nations, the Universal Declaration of Human Rights ('UDHR'); ${ }^{44}$ the International Covenant on Civil and Political Rights ('ICCPR'), ${ }^{45}$ and the ICESCR.

A positivist approach is more conservative in nature, as the developments via international agreement on core norms are slow. Some look at a whole range of statements, declarations and practices, seeking to argue human rights have entered the realms of customary law. ${ }^{46}$ As Philip Alston notes

$42 \quad$ See Chapter 3.

43 See Chapter 14.

44 GA Res 217A (III), UN Doc A/810, 71 (1948).

45 Opened for signature 16 December 1966, 999 UNTS 171 (entered into force 23 March 1976).

46 For example, Theodor Meron, Human Rights and Humanitarian Norms as Customary Law (Oxford University Press, Oxford, 1989). 
however, few would include economic and social rights through this form of analysis. ${ }^{47}$

Even a purely treaty-based approach has interpretational uncertainties. Integrating WTO and human rights under a positivist framework requires consideration of the legal implications of differing but overlapping membership of the two international legal regimes, positivist approaches to identifying any hierarchy or other means of resolving conflict, such as through the use of the norms contained in the Vienna Convention on the Law of Treaties ('VCLT'), ${ }^{48}$ and many difficult dispute settlement issues such as interpretation of rules, approaches to evidence, standing and jurisdiction and sources of law. For example, the WTO is criticized for not allowing civil society or individuals to have standing. Jurisdictional questions can also be raised as to whether a panellist who is empowered solely through the WTO Dispute Settlement Understanding can nevertheless consider other international law norms.

There is also a question of interpretation of meaning of any express norms. For example, what do we mean by the 'highest attainable standard' for health ${ }^{49}$ The more there are difficulties in interpreting individual norms, the more difficulties there might be for any adjudicator seeking to resolve linkage and trade-off issues between trade and human rights. In addition there are important reservations and exceptions within the human rights treaty provisions that require similar balancing as occurs under Article XX GATT 1994. Examples include 'emergencies' as expressed in Article 4 ICESCR and 'public policy' requirements per Article 8(2) ICESCR.

There may also be conflicts between different human rights norms. On one level, all are equal in importance and are interdependent ${ }^{50}$ but some are written in softer language which would be relevant from a positivist perspective. In addition, they often impose differing constraints on how governments should act and how rights should be enforced. Thomas Cottier has pointed out that some human rights are suitable for articulating immediate individual legal rights, while others are of a programmatic nature, needing elaboration and guidance legislatively. ${ }^{51}$ Yet not all would agree on which fall into either cate-

47 Philip Alston, 'Ships Passing in the Night: The Current State of the Human Rights Development Debates Seen Through the Lens of the Millennium Development Goals' (2005) 27 Human Rights Quarterly 755, 773.

48 Opened for signature 23 May 1969, 1155 UNTS 331 (entered into force 27 January 1980).

49 Article 12 ICESCR; Paul Hunt, The Right of Everyone to the Enjoyment of the Highest Attainable Standard of Physical and Mental Health, Report of the Special Rapporteur, Addendum, Mission to the World Trade Organisation, UN Doc E/CN.4/2004/49/Add.1 (1 March 2004).

50 Article 2 UDHR.

51 Cottier, above n 21, 112. 
gory. Sarah Joseph's contribution on democratic deficit also analyses which specific human rights might arguably be breached as a result of WTO norms and practices. ${ }^{52}$ Philip Alston deals with the question whether poverty itself involves a breach of human rights. ${ }^{53}$

One difficulty is seeking to integrate various potentially conflicting norms that arise through different legal sources. Here, as in any legal system, there needs to be a balancing device, whether this is some form of proportionality test as applied in EU and Canadian constitutional law or the reasonableness test of the WTO Appellate Body per Article XX GATT 1994 jurisprudence. ${ }^{54}$ There are also risk management issues and the degree of scientific certainty alluded to above in relation to the SPS Agreement.

A further issue in a positivist debate as to the ambit of human rights is whether the rights are limited to negative rights against undue interference or entail positive rights that impose obligations on others to help their attainment. While ICESCR clearly includes positive rights, the interpretation challenge still exists, particularly in the face of the softer language of some norms. A right might be stated more positively, but could still be expressed more in aspirational language as well. Furthermore, if a positive right requires considerable expenditures to be fulfilled, to what extent is it an inherent right where a government has limited resources? The debate would also lead to some positivist philosophers concluding that ICESCR is generally aspirational and not about existing human rights. Paul Hunt believes that this argument is misleading because State intervention is also required for the protection of civil and political rights as well as economic rights. Both sets of rights may require State intervention and a substantial amount of expenditure and should not be distinguished on this basis. ${ }^{55}$

$52 \quad$ See Chapter 12.

53 Philip Alston, above n 47, $785 \mathrm{ff}$.

54 Donald Regan, 'The meaning of "Necessary" in GATT Article XX: The Myth of Cost-Benefit Balancing' (2007) 6 World Trade Review 347; Federico Ortina, From 'Non-Discrimination' to 'Reasonableness': A Paradigm Shift in International Economic Law? (2002) Jean Monnet Program, www.jeanmonnetprogram.org/papers/ 05/050101.html at 12 December 2008; OHCHR, Human Rights and World Trade Agreements: Using General Exception Clauses to Protect Human Rights (2005) UNHCHR, http://www.ohchr.org/Documents/Publications/WTOen.pdf at 12 December 2008.

55 Paul Hunt, 'Reclaiming Economic, Social and Cultural Rights' (1993) Waikato Law Review 141, 153. For arguments that the rights carry concomitant obligations see Office of the High Commissioner for Human Rights ('OHCHR'), Draft Guidelines: Human Rights Approach to Poverty Reduction Strategies (2002) OHCHR, [13], www.unhchr.ch/development/povertyfinal.html at 14 December 2008; United Nations Development Program, Human Development Report 2003 (United Nations, Geneva, 2003) 28. 
Even a narrow positivist approach could also lead to questions as to the role of some alleged rights not expressly covered. An example might include rights not seen themselves as established human rights, but which might nevertheless be argued to be inherent elements of such rights by reason of being necessary preconditions for the attainment of express human rights. For example, Amartya Sen saw freedom to exchange goods as a human right given the relationship to the right to work and the right to food. ${ }^{56}$

James Harrison has addressed our central question as to the compatibility of the two regimes from a perspective that concentrates on a positivist conception of human rights even though he himself does not presume that such rights should be so limited ${ }^{57}$ Nevertheless, within that framework, he concluded that there were still particular problems although he suggested that there were 'few inherent actual conflicts'. ${ }^{58}$ He noted the trend towards WTO rules aiming at more internal regulation of Members in fields that cannot all be justified under neo-classical economic postulates of trade liberalization. While economists could debate the characterization, political science perspectives suggest no surprise when powerful Members use the WTO to impose such things as intellectual property protections that are far removed from the trade barrier concerns that faced the GATT from its inception. Harrison also raises concerns as to conditionality-based trade restrictions that aim to promote human rights. He concludes that fear of scrutiny under the WTO acts as a disincentive to such action against extreme human rights abuses. He also notes that use of such mechanisms under regional or preference regimes comes with insufficient scrutiny mechanisms to counter imbalances in power between donor and donee. ${ }^{59}$ This dual concern suggests how delicate the balancing needs to be if both too much and too little scrutiny can be legitimate problems as circumstances change. The regulatory chill factor is in part proportional to the uncertainty in the rules and Harrison calls for more precision in articulation of key concepts. ${ }^{60}$

The challenges grow exponentially when we move beyond a purely positivist approach to the identification of human rights norms. ${ }^{61}$ If the basis of human rights is philosophical and not purely within positivist notions of legal philosophy, what are its sources? Is it religious as per natural law, can it be devised from moral philosophy, or from the specific field of ethics as Peter

$56 \quad$ Amartya Sen, Development as Freedom (Knopf, New York 1999) 26.

57 James Harrison, The Human Rights Impact of the World Trade Organisation (Hart Publishing, Oregon, 2007).

58 Ibid 249.

59 Above, n 57, 121.

60 Above, n 57, 250.

61 Burns Weston, 'Human Rights' (1984) 3 Human Rights Quarterly 257, 259. 
Singer asserts, ${ }^{62}$ can it be even justified economically or under game theory as the basis of a stable and sustainable society? While some human rights advocates eschew an attempt to articulate philosophical foundations, ${ }^{63}$ Jerome Shestak has observed that there are a range of practical reasons to consider the philosophic foundations of human rights. Understanding the foundations may promote the authority of the international law of human rights:

[h] ow one understands the meaning of human rights will influence one's judgment on such issues as which rights are regarded as universal, which should be given priority, which can be overruled by other interests, which call for international pressures, which can demand programs for implementation, and for which one will fight. ${ }^{64}$

Michael Freeman argues that the positivist approach misrepresents human rights and can have dangerous implications. In his view, '[o]ne appeals to human rights precisely when legal institutions fail to recognize and enforce them. If legal positivism were true, an important basis for criticizing unjust legal systems would be eliminated'. ${ }^{65}$

A converse argument is that we should simply concern ourselves with the actual problems in the world and not get bogged down in the competing theories. Thus even if we have differing views as to global justice, we can still readily say that we wish to do something about extreme poverty as is evidenced by the Millennium Development Goals as adopted. ${ }^{66}$ Nevertheless, a concern for the philosophical questions will help us understand whether we have gone far enough. To the extent that equality is an element of justice, concerns for the world's poor need to arise far earlier than when they are found to be starving.

62 Peter Singer, One World: The Ethics of Globalization (Yale University Press, New Haven, 2002).

63 In fact it was the very lack of a consistent view about the nature of human rights that led James Harrison to limit his analysis of the WTO and human rights to a positivist one: Harrison, above $\mathrm{n}$ 57. Philip Alston has also cautioned against an unprincipled proliferation of alleged human rights: Philip Alston, 'Conjuring Up New Human Rights: A Proposal for Quality Control' (1984) 78 American Journal of International Law 607.

64 Jerome J Shestak, 'The Philosophic Foundations of Human Rights' (1998) 20 Human Rights Quarterly 201, 201-2.

65 Michael Freeman, Human Rights: An Interdisciplinary Approach (Policy Press, Cambridge, 2002) 12.

66 Thomas Nagel, 'The Problem of Global Justice' (2005) 23 Philosophy and Public Affairs 113, 118; UN, Millennium Development Goals (2000) UN, www.un.org/millenniumgoals/ at 14 December 2008; UN, United Nations Millennium Declaration, GA Res 55/2, UN GAOR, 55th sess, 8th plen mtg, UN Doc A/Res/55/2 (8 September 2000). 
Philosophical views about human rights have varied significantly as different philosophical theories as to law, politics and liberty have emerged. Legal positivism, which dominated much of jurisprudential thought in the nineteenth and twentieth centuries, is the natural justification for the positivist view of the international law of human rights. At the extreme, a positivist perspective did not treat international law as a proper legal system because the absence of a sovereign authority with enforcement powers was antithetical to its notion of law as such. ${ }^{67}$ The more expansive view stems from the natural law tradition, beginning with religion-based notions of fundamental rights and values. Secular developments in natural law theory also provided a justification for international law as law. The natural law theories of scholars such as Grotius were particularly relevant in justifying international law per se as a mechanism to promote the moral imperative of peaceful and harmonious cooperation between people and nations. ${ }^{68}$ In considering the rights of individuals and the role of government, John Locke argued that the fundamental right of individuals was for life, liberty and property, with governments being a result of a social contract to avoid the worst aspects of interpersonal behaviour under an unconstrained state of nature. ${ }^{69}$ The French Philosophers, particularly Rousseau and Voltaire, built upon these ideas, in turn inspiring developments in America and its domestic Bill of Rights. ${ }^{70}$

Some philosophical perspectives were closely aligned with certain economic perspectives. For example, the utilitarianism of Jeremy Bentham calls for governmental policies that promote the greatest benefit for the greatest number. That is less concerned with the individual and certainly the least fortunate individual. As a result, Bentham was sceptical of the notion of human rights. ${ }^{71}$

67 John Austin, The Province of Jurisprudence Determined (Weidenfeld and Nicholson, London, 3rd edn, 1954).

68 Shestak, above n 64, 206.

69 John Locke, Two Treatises of Government (Cambridge University Press, New York, Peter Laslett ed., 1963).

70 See, for example, Jean-Jacques Rousseau, The Social Contract (Penguin, London, Maurice Cranston ed., 1968).

71 Modern scholars have also questioned the determinacy of human rights: for example, Chris Brown, 'Universal Human Rights? An Analysis of "Human-Rights Culture" and its Critics' in R G Patman (ed.) Universal Human Rights? (Palgrave Macmillan, London, 2000) 31, or have argued that they need to be understood in their historical context, for example, Norberto Bobbio, The Age of Rights (Policy Press, Cambridge, 2nd ed., 1996); Jack Donnelly, Universal Human Rights in Theory and Practice (Cornell University Press, Ithaca, 2003); Eugene Kamenka, 'Human Rights: Peoples' Rights' in James Crawford (ed.) The Rights of Peoples (Oxford University Press, New York, 1988) 127. Critical legal studies indeterminacy challenges have also been directed to human rights themselves. See for example Duncan Kennedy, $A$ Critique of Adjudication (Cambridge University Press, Cambridge, 1997). 
From a human rights perspective, it is not only the nature of these philosophical schools of thought, but also their focus that is important. Locke's views begin with individual rights and postulate a minimal role for government, purely in order to effectively support those rights. On the other hand, the utilitarian perspective looks at the collective good rather than the individual's rights. ${ }^{72}$ Some of the excesses of the twentieth century show how problematic notions of the collective good may prove to be. The post-World War II international legal framework, including the United Nations and the Bretton Woods system, including the related GATT as the precursor to the WTO, were in part inspired by greater thought about the value of individual liberty and mechanisms which might protect it. The Kantian perspective has been particularly influential in developing a moral philosophy that supports cooperation and values and behaviour that ought to be applicable to all. ${ }^{73}$ Kant argued that humans and humanity should be seen as ends and not means, a view which resonates strongly with the core values espoused in the UDHR. He also argued that a cosmopolitan view of such rights would support our aspiration to perpetual peace. ${ }^{74}$

While there is certainly no consensus on the basis of a non-positivist theory, certain recent scholars have been particularly influential in advancing the debate. Ronald Dworkin sought to reconcile natural rights and utilitarian perspectives in his seminal work, Taking Rights Seriously ${ }^{75}$ Probably the most influential modern philosophical perspective is that of John Rawls, who sought to identify rights and duties within a society based on a coherent theory of justice. Using a thought experiment of a negotiated social contract between persons conducting the exercise behind a 'veil of ignorance', he argued that two principles of justice would be selected. The first is that 'each person is to have an equal right to the most extensive total system of equal basic liberties compatible with a similar system of liberty for all'. ${ }^{76}$ The second principle asserts that 'social and economic inequalities are to be arranged so that they are both: (a) to the greatest benefit of the least advantaged, consistent with the just savings principle, and (b) attached to offices and positions open to all under conditions of fair equality of opportunity'. ${ }^{77}$

At first, it might have been thought that the second principle was a justification for redistributional rules at the international level in favour of the least

72 Shestak, above n 64, 212.

73 Fernando Teson, 'The Kantian Theory of International Law' (1992) 92 Columbia Law Review 53.

74 Immanuel Kant, 'Perpetual Peace: A Philosophical Sketch' in H Reiss (ed.) Kant - Political Writings (Cambridge University Press, Cambridge, 2nd edn, 1991) 107.

75 Ronald Dworkin, Taking Rights Seriously (Duckworth, London, 1977).

76 John Rawls, A Theory of Justice (Harvard University Press, Cambridge, 1971) 302.

77 Ibid. 
advantaged countries, although Rawls did not assert this in that book. Indeed in due course, he argued to the contrary in a separate book, The Law of Peoples. ${ }^{78}$ One difficulty is that for obvious reasons, human rights scholars never sought to incorporate trade law norms into a comprehensive philosophical theory of human rights until such time as the WTO and international economic law were seen as problematic. Human rights law was first concerned with the most egregious crimes against humanity and individuals. More recently it is dealing with the more intellectually challenging concern with the notion of socio-economic justice. It has only been relatively recently that the relationship between these two fields has begun to be examined. These themes are explored in Patrick Emerton's chapter which deals with the Rawls/Pogge debate about the duty of industrialized countries towards developing countries. Thomas Pogge has taken issue with Rawls' argument as to why his justice principles do not operate internationally. ${ }^{79}$ Rawls applied his theory of justice on a two-step basis. Once persons had collected into a people based on a social contract they would owe different duties to other peoples. Decent societies would not only wish to help others but it would be strategically sensible to stabilize the world. Rawls argued that the main reason for poverty is the lack of institutional infrastructure. If the cause of poverty is institutional defects, then in his view, the limits of the moral obligation are to assist in developing these. Pogge challenges this view on a range of levels, both factual and moral. Patrick Emerton explores that debate and also seeks to identify the core content of human rights that might flow from the basic theory of justice. ${ }^{80}$

Modern proponents of a non-positivist theory of human rights have based their arguments on dignity, ${ }^{81}$ justice ${ }^{82}$ and liberalism. ${ }^{83}$ Philip Alston has made

78 Rawls, The Law of Peoples, with the Idea of Public Reason Revisited (Harvard University Press, Cambridge, 1999).

79 Thomas W Pogge, Kant, Rawls and Social Justice (PhD Thesis, Harvard University, 1983); Thomas W Pogge, 'An Egalitarian Law of Peoples' (1994) 23 Philosophy and Public Affairs 195; Thomas W Pogge, World Poverty and Human Rights (Polity Press, Cambridge, 2002).

80 Chapter 6.

81 For example, Oscar Schachter, 'Human Dignity as a Normative Concept' (1983) 77 American Journal of International Law 848; Jack Donnelly, Universal Human Rights in Theory and Practice (Cornell University Press, New York, 2003); Michael J Perry, Towards a Theory of Human Rights (Cambridge University Press, Cambridge, 2007); Raymond J Vincent, Human Rights and International Relations (Cambridge University Press, Cambridge, 1986); Louis Hencken (ed.), Human Dignity: The Internationalisation of Human Rights (Aspen Institute for Humanistic Studies, New York, 1979).

82 Rawls, above n 76; Ronald Dworkin, above n 75.

83 David P Forsythe, Human Rights in International Relations (Cambridge University Press, Cambridge, 2006). 
the point that general terms such as equity, dignity and governance need to be rooted in identified standards ${ }^{84}$ Christian Tomuschat has argued for certain human rights deductively as an essential element of a viable legal order. ${ }^{85}$ Alston postulated a revision of Tomuschat's thesis namely:

$[\mathrm{N}]$ o right should be excluded when the following two conditions are present: (i) the right is indispensable to a meaningful notion of human dignity (upon which human rights are based) and (ii) the satisfaction of that right is demonstrably within the reach of the government in question assuming reasonable support from the international community. 86

Sociological and anthropological perspectives may also be relevant in the identification of the ambit of human rights. Given that human rights law has emanated from the international legal system which has been dominated by Western thought and power, some have questioned whether its values, including human rights norms, can be challenged from the perspective of cultural relativism. John Finnis contends that a comprehensive survey of different anthropological literature shows that there are universal basic values shared by all cultures, albeit that these values may be realized in different ways. He argues that such universal values include, inter alia, concern for human life, concern for truth and for education. ${ }^{87}$ Michael Trebilcock notes the policy advocacy of many globalization critics 'who on the one hand ostensibly oppose the imperialistic expansion of Western cultural influences, while at the same time selectively promoting distinctly homogeneous concepts of universal human rights, labour standards and environmental protection'. ${ }^{88}$

$84 \quad$ Philip Alston, above n 47, 760.

85 Christian Tomuschat, Human Rights: Between Idealism and Realism (Oxford University Press, Oxford, 2004) 35.

86 Philip Alston, above n 47, 774.

87 John Finnis, Natural Law and Natural Rights (Clarendon Press, Oxford, 1980) 83. See also Arvind Sharma, Are Human Rights Western? (Oxford University Press, New York, 2006); Richard A Wilson (ed) Human Rights, Culture and Context: Anthropological Perspectives (Pluto Press, London, 1997); A Pollis and P Schwab (eds) Human Rights: Cultural and Ideological Perspectives (Praeger, New York, 1979); Fernando Teson, 'International Human Rights and Cultural Relativism' (1985) 25 Virginia Journal of International Law 869.

88 Michael J Trebilcock, 'Critiquing the Critics of Economic Globalization' (2005) 1 Journal of International Law and International Relations 213, 217. 


\section{PHILOSOPHICAL PERSPECTIVES ON THE BROADER DEBATE}

The previous section looked at philosophy in the context of defining the ambit of human rights, but there are a range of other philosophical questions that present themselves when we look at the compatibility between the regimes. The question to ask in tandem is what is the philosophical justification for trade liberalization. As noted above, efficient solutions by definition increase total welfare. They do not guarantee allocation in ways that all would see as just, but at least a larger total allocatable amount provides greater opportunities for just distributions, however they are to be defined. The economic premise is therefore the first issue. The WTO is bound up in the economics of efficiency, so if it does not even promote efficiency or raise total welfare it would not be a just outcome for that reason alone. Even where it raises welfare, because it has no distributional norms, the justice of its immediate outcomes depends on one's views as to distributive justice ranging from the classical utilitarian perspective to Rawlsian perspectives. To the latter school of thought, at the national level, even an optimal outcome from an efficiency perspective would not be fair without any adjustment mechanisms along the way. A philosophical argument in favour of a libertarian free market was provided by Robert Nozick. ${ }^{89}$ Because Nozick's libertarian perspective includes arguing that a person has the right to the fruits of their labour, he argues against redistributive taxation policies as being tantamount to forced labour.

A key issue is how to respond to data that shows increased wealth of the very poor in most societies, but also even more rapidly increasing disparities between rich and poor individuals and generally between North and South. Again a Rawlsian perspective has concerns with this, although his own work showed that there are complex questions of liberal political philosophy when one moves from national to international perspectives.

There are a number of other specific philosophical questions posed by aspects of WTO activities. These might include: the notion of sovereignty and the propriety of extra-territorial norms in cases such as Shrimp/Turtle where US laws sought to ban shrimp imports from foreign suppliers who did not do enough to protect endangered sea turtles; the more general relationship between sovereignty and justice, ${ }^{90}$ unequal and unconscionable bargaining

90 Thomas Nagel has pointed out the need to consider justice alongside concepts of sovereignty. This forces us to choose between cosmopolitan and political constructs of justice as epitomized in the Pogge/Rawls debate. Nagel, above n 66, p 120; Peter Singer, One World (Yale University Press, New Haven, 2002). A cosmopolitan view 
within negotiating Rounds; ${ }^{91}$ de facto discrimination through such phenomena as tariff escalation, where the WTO's reciprocal and unconstrained negotiating forum tends to lead to negotiated outcomes where there are higher tariffs on products that are of most interest for developing country exports and generally weaker norms in fields such as agriculture.

There are also philosophical questions as to adjudicatory methodology such as in relation to approaches to interpretation. Once again the chapter by Howse and Teitel argues strongly for an approach which pays sufficient deference to human rights. This methodology is strongly reinforced in the chapter by ErnstUlrich Petersmann.

Justice issues also have temporal dimensions. This is because economics argues that trade liberalization that can be expected to cause short-term harm to inefficient traders and consequential problems for employees in that sector will lead to increased welfare in the long term. There is then a philosophical question as to the degree to which economic harm can be allowed to occur to current citizens, with a view to providing greater benefits for future citizens. Again the question only becomes relevant if the economic arguments are hypothesized to be true. This again reminds us that the different interdisciplinary perspectives must be integrated. Another example of the intersection between philosophy and economics is the Pogge/Rawls debate alluded to above. Pogge based his views, in part at least, on a belief that international economic law causes harm to the extreme poor, while Rawls took issue with that assertion. Philosophers must then turn for assistance to economists. Economics may also help to resolve other tensions such as the morality underpinning utilitarianism.

\section{ECONOMIC PERSPECTIVES}

While few if any would support the idea of efficiency as an ultimate goal, economists argue that it is an extremely desirable means to the attainment of more meritorious goals. As noted above, neo-classical economics argues that many utilitarian policies would provide sufficient welfare gains to allow the winners to fully compensate the losers and still be better off. As also noted, the WTO is premised on the economic theory of comparative advantage as a means to maximize wealth through specialization and trade. Neo-classical economics also points out that trade barriers on imports adversely affect the import country's export sector as well as imposing excessive costs on

was presented by Charles Beitz, Political Theory and International Relations (Princeton University Press, Princeton, 1999).

91 This issue is discussed in Chapter 12 in the context of democratic deficit. 
consumers, and that growth is generally better than redistribution alone as a mechanism to increase welfare. Neo-classical economics also points to the regulatory importance of price signals as incentives towards efficient allocation of resources. The Coase theorem also points to the regulatory benefits in adopting the most efficient response to the regulation of social issues such as environmental protection. ${ }^{92}$

An efficient solution is one where total value is maximized and hence at least increases the potential distributable benefits to the individuals within a society. While there may be winners and losers from any market-based endeavour, neo-classical economic theory asserts that a domestic political system can redistribute the efficiency gains from trade liberalization to those who suffer in the short term, either through immediate income transfers or through retraining schemes and the like. Economists describe this as a Kaldor/Hicks transfer payment at the domestic level, where winners from efficiency gains are able to fully compensate losers and still be better off. Neoclassical economic theory also postulates that even though there will commonly be short-term losers, the efficiency gains in the short term will provide greater opportunities for short-term losers in the long term beyond the option of immediate compensatory transfers. Economists describe this as a Kuznets curve analysis which predicts short-term losses before long-term gains.

Such a market-based system contemplates transfers but does not mandate them, leaving this as economic theory does, to domestic political systems. In this sense, the WTO is not inherently utilitarian, simply because it leaves the distributional justice questions to domestic politics.

Those in the early 'pro-WTO' camp in the human rights debate tended to rely on the above postulates of liberal trade theory and tended to ignore the problem of the observable disparity of benefits from trade and the challenge as to whether there is any systemic bias against the extreme poor. Many supporters tended to rely on the neo-classical economic views above, that disparities will be alleviated over time and/or are domestic redistribution issues outside the purview of economic prescription. Yet the utility of liberal trade policies as a means to promote human development is not without its critics and the degree of poverty and disparities in wealth cannot be ignored, whatever their true cause. ${ }^{93}$ As the current problems in the world economy

92 Ronald H Coase, 'The Problem of Social Cost' (1960) 3 Journal of Law and Economics 1 .

93 For an analysis of some of the key challenges see Trebilcock, above $\mathrm{n} 88$. For survey analyses of the challenges from development theory see Kevin E Davis and Michael J Trebilcock, 'The Relationship Between Law and Development: Optimists versus Skeptics' (Working Paper No 08-14, NYU School of Law, Public Law and Legal 
show, markets will inevitably fail without appropriate regulatory mechanisms. It is extremely difficult to find the right balance between regulation and liberalization and to have that adopted and nurtured by a democratic constituency subject to pressures from vested interests. This issue will be discussed further below in relation to the political dimension.

Returning to economic concerns, debates about the incontrovertible data as to an unconscionable amount of truly poor people in the world, ${ }^{94}$ bring us to complex causation questions and in turn, philosophical debates dependent upon the conclusions on those causation questions. Sceptical economists and some philosophers have relied heavily on the data as to extreme poverty as part of a critique of liberalization. For example, Pogge noted that a quarter of the world's population lives below the international poverty line. ${ }^{95}$ Complex causation questions have been noted. For example, is the disparity in gains from trade in favour of industrialized countries proof of exploitation or is it the natural corollary of higher labour productivity in the richer countries? Is the latter shown by China taking over textiles market share from countries such as the Philippines and Bangladesh? Economics has tried harder in recent times to explain such outcomes. More recently, much has been done in modelling growth and analysing developing country economic performance. ${ }^{96}$ At times the results will be mixed in terms of benefits and detriments. For example, Winters et al. ${ }^{97}$ survey the empirical literature and note increased income from trade liberalization but also note higher volatility through variances in prices and income sources.

Many human rights critics of the trade regime have looked to the work of economists such as Dani Rodrik that seeks to draw sceptical causal conclusions from statistical data and econometric modelling. For example, Rodrik compared Mexico, a participant in the WTO and NAFTA, unfavourably with

Theory Research Paper Series, 2008); John K M Ohnesorge, 'Development Theory: Law and Development Orthodoxies and the North East Asian Experience' (2008) 28 University of Pennsylvania Journal of Economic Law 219; Francisco Rodriguez and Dani Rodrik, 'Trade Policy and Economic Growth: A Skeptic's Guide to the CrossNational Evidence' (Working Paper No W7081, National Bureau of Economic Research, Harvard University, 1999).

94 Detailed data is provided in Chapter 4. See also Daron Acemoglu and Ventura Jaume, 'The World Income Distribution' (2002) 117 Quarterly Journal of Economics 659.

95 Pogge, above n 79 (2002), 7-9.

96 For example, John M Antle and Gregg Heidebrink, 'Environment and Development: Theory and International Evidence' (1995) 43 Economic Development and Cultural Change 603.

97 Alan L Winters et al. (2004) 'Trade Liberalization and Poverty: The Evidence So Far' (2004) 42 Journal of Economic Literature 72. 
Vietnam, then outside the WTO system. ${ }^{98}$ The contribution in this volume from David Kinley, Hai Nguyen and Odette Murray ${ }^{99}$ adds a more recent analysis of Vietnam through the time frame when it acceded to the WTO Agreement. Their chapter looks critically at some of the pressures imposed on developing countries through their relationship with more powerful trading partners under this system, which again brings the political science perspective into our analysis. Even if Rodrik's comparative cautions are appropriate, however, one needs to be careful as to what conclusions one would draw. If Vietnam has advanced more favourably outside of the WTO system than Mexico has done within it, do we now expect a downturn in Vietnam's economic welfare and human rights as a result of joining the system? If so, for what reasons? If this does not eventuate, what implications would this have for our theoretical perspectives?

A number of leading economists have questioned aspects of free market equilibrium analysis. Alan Blinder has cautioned as to the implications of offshoring of impersonal jobs, although he did so from the perspective of the impact upon a developed country, the USA. He points to the fact that significant transitional shocks creating millions of losers lead to political problems from shifts in trading patterns. ${ }^{100}$ Some economists seek to analyse markets from the perspective that they are significantly more complex systems than is theoretically postulated. ${ }^{101}$ Nobel Prize winner George Akerlof has presented a detailed study of the role of psychological norms as they affect neo-classical postulates. ${ }^{102}$ Psychological insights into mass commercial behaviour underlie the behavioural finance school of economics. ${ }^{103}$ Psychologists have also argued that as nations become wealthier, such wealth ceases to be a good indicator of general well-being. ${ }^{104}$

Pranab Bardhan in his chapter ${ }^{105}$ reminds us of the perennial research prob-

98 Dani Rodrik, The Global Governance of Trade as if Development Really Mattered (United Nations Development Program, New York, 2001) 21ff.

99 See Chapter 9.

100 Alan S Blinder, 'Offshoring: Big Deal, or Business as Usual?' (CEPS Working Paper No 149, June 2000), www.princeton.edu/ ceps/workingpapers/ 149blinder.pdf at 15 December 2008.

101 See for example W Brian Arthur et al. (eds), The Economy as an Evolving Complex System II (Addison-Wesley, Reading, 1997).

102 George A Akerlof, 'The Missing Motivation in Macro Economics' (2007) 97 American Economic Review 5.

103 See for example Robert Shiller, 'Behavioural Economics and Institutional Innovation' (2005) 72:2 Southern Economic Journal 269.

104 Ed Diener and Martin E P Seligman, 'Beyond Money: Toward an Economic of Well-Being' (2004) 5:1 Psychological Science in the Public Interest 1.

105 Chapter 4. 
lem of correlation versus causation. He points out that past economic regression studies are all flawed. These can only look at correlations and also have analytical problems. For example, why have China and India grown; is it trade, or internal infrastructure, land reform, internal migration, anti-poverty programs internally or the like? Why has sub-Saharan Africa fallen behind? Is it instability, war, civil conflict, and corruption, which frighten off foreign investors and traders? Pranab Bardhan's chapter seeks to drill down to a more analytical perspective on the various ways that trade liberalization may impact upon the poor as a discrete group. He finds a complex picture where benefits are largely dependent on the domestic political and economic institutions of the countries concerned.

Some analysts take an economic history perspective and present a pessimistic picture as to the extent of time that developing countries need to suffer social and political injustice while pursuing growth. ${ }^{106}$ Joseph Stiglitz has presented an insider's critique and in part has highlighted the natural economic observation that asymmetrical information and market power and inadequate institutions will not lead to efficient outcomes. Furthermore, he sees some of these problems as ethical issues. Rodrik and Stiglitz have not abandoned economic theory, however. Stiglitz notes that developing countries cannot afford the inefficiency losses from poor resource allocation and policies that are a disincentive to foreign investment and which promote an exodus of their best and brightest. ${ }^{107}$ Indeed in another publication, Rodrik accepts that all countries have been shown to succeed in growth if they integrate with the global economy, install adequate institutional environments to protect property rights and enforce contracts and adopt sound government financial practices. $^{108}$

Another aspect of economic analysis would look at the interrelationship between trade regulation and human rights. We can consider the positive and negative correlations between the regimes that economic theory might predict. An example of a negative impact is the effect of TRIPS norms on the generic pharmaceutical industry. On the other hand, many trade law reforms would be expected to have positive effects on some human rights at least. An example

106 Sylvia Ann Hewlett, 'Human Rights and Economic Realities: Tradeoffs in Historical Perspective' (1979) 94 Political Science Quarterly 453.

107 Joseph E Stiglitz, 'Two Principles for the Next Round, or How to Bring Developing Countries in from the Cold' (2000) 23 World Economy 438. See also Joseph Stiglitz and Andrew Charlton, Fair Trade for All: How Trade Can Promote Development (Oxford University Press, Oxford, 2007); Joseph Stiglitz, Making Globalisation Work (Allen Lane, New York, 2006).

108 Dani Rodrik, One Economics, Many Recipes: Globalisation, Institutions and Economic Growth (Princeton University Press, Princeton, 2008). 
would be the positive environmental impact of reducing agricultural subsidies. ${ }^{109}$ There is also the correlation between higher stages of development and demand for higher levels of human rights, with environment again being the key example, although we might need to factor in the negative impact on the environment of commercial activity. ${ }^{110}$

Another NGO challenge that economists have sought to examine is whether trade competition leads to a race to the bottom in terms of the human rights infrastructure that might impose costs on traders. Examples would include direct environment, labour and social welfare standards or the indirect impact of reduced government revenue through tax competition aimed at attracting foreign investment. ${ }^{111}$ The scholarship to date suggests that there is little evidence of such a race. ${ }^{112}$

Economics also provides insights as to the relative efficiency of direct versus indirect policy instruments. For example, direct allowance of labour migration would do much more for labour standards than trying to force foreign policy changes through a social clause. Trade in goods is simply a substitute for trade in other factors. Another direct labour approach would be to provide income transfers to stop child labour.

Another specific challenge is whether sanctions should be permitted in aid of human rights goals and whether the WTO norms unduly interfere with this. ${ }^{113}$ To date, many economic and political commentators challenge the

109 Daniel C Esty, 'Greening World Trade' in J J Schott (ed.) The World Trading System: Challenges Ahead (Peterson Institute for International Economics, Washington DC, 1996).

110 Antle and Heidebrink, above n 96.

111 It is worth noting that any problems with investment as opposed to trade policy fall outside the range of legitimate criticisms of the WTO given its limited brief. 112 For example, Robert C Feenstra and Gordon H Hanson, 'Global Production and Inequality: A Survey of Trade and Wages' in E Kwan Choi and James Harrigan (eds) Handbook of International Trade (Blackwell, Oxford, 2002) Ch 6. Eskeland and Harrison found no evidence of correlation between foreign investment and home country pollution abatement costs and also found that foreign companies in developing countries are cleaner and more energy efficient than locals: see generally Gunnar A Eskeland and Ann Harrison 'Moving to Greener Pastures? Multinationals and the Pollution Haven Hypothesis' (2003) 70 Journal of Development Economics 1. This is not to say there are not significant instances of inappropriate multinational behaviour or the need for developments in corporate social responsibility. This literature simply relates to the challenge as to whether there is a systemic race to the bottom implied by the notion of competition per se.

113 See for example Patricia Stirling, 'The Use of Trade Sanctions as an Enforcement Mechanism for Basic Human Rights: A Proposal for Addition to the World Trade Organisation' (1996) 11 American University Journal of International Law and Policy 1. 
benefits of such strategies. ${ }^{114}$ Most commentators argue that they hurt innocent parties. Thus they take away some human rights to promote others, raising 'ends justifying means' philosophical questions. It is also difficult to apply sanctions in a non-discriminatory way, that is target everyone who needs change, or decide where the cut-off line is. They often involve double standards. They generally have no review mechanism. Sanctions will not work when the target prefers to forgo the gains from trade, although this might mean that trade sanctions work best on those who believe in trade the most and who benefit the most from it. Even when changes are made, they are often poorly administered. ${ }^{115}$ Political science would suggest that for sanctions to be approved there will usually need to be an alliance between altruists and protectionists, hence encouraging protectionism.

Economics could also look at the efficiencies or otherwise of trade and human rights regimes and the cost/benefit of linkage. ${ }^{116}$ Failing to link has extra transaction costs, fragmentation and non-coherence issues. There are differing approaches; one would be to prioritize. Another is to have a streaming mechanism such as Article XX GATT 1994; a third approach is to simply relax the standards in the substantive norms and provide for greater deference. Caroline Foster's chapter calling for deference to domestic public opinion is an example of the latter, as are the chapters of Howse and Teitel and Petersmann demanding interpretation consistent with human rights norms. ${ }^{117}$

There has also been some analysis of the WTO from a new institutional economics perspective. ${ }^{118}$ An important question is to consider what we should be properly comparing with what. To simply analyse a particular system without considering its alternatives makes it too easy to criticize and

114 See, for example, Gary C Hufbauer et al., Economic Sanctions Reconsidered (Peterson Institute for International Economics, Washington DC, 3rd edn 1990).

115 See generally Jim Rollo and Alan L Winters, 'Subsidiarity and Governance Challenges for the WTO: The Examples of Environmental and Labour Standards' (2000) 23 The World Economy 561.

116 Jack L Goldsmith and Eric A Posner, 'The Theory of Customary International Law' (1999) 66 University of Chicago Law Review 1113; Jeffrey L Dunoff and Joel P Trachtman, 'Economic Analysis of International Law' (1999) 24 Yale Journal of International Law 1; Alan Sykes, 'International Trade and Human Rights: An Economic Perspective' in F M Abbott et al. (eds) International Trade and Human Rights: Foundations and Conceptual Issues (University of Michigan Press, Detroit, 2006) 69.

117 See, respectively, Chapters 11, 2, and 3; see also Chapter 12.

118 Based on the earlier works of economists such as: Coase, above n 92; Oliver E Williamson, The Economic Institutions of Capitalism (Free Press, New York, 1985); Beth V Yarbrough and Robert M Yarbrough, Cooperation and Governance in International Trade: The Strategic Organizational Approach (Princeton University Press, Princeton, 1992). 
misunderstand the problems of second-best analysis. Economics might thus look at the cost/benefit of the system as opposed to unconstrained protectionism, uncertainty, and the impact of a shift to bilateralism. Thus a key question is whether major economic powers would be more or less able to exploit the poor absent a regulatory mechanism such as the WTO? This again leads on to political science questions, to be discussed below.

Methodologically, we might also need to consider second-best analysis where we consider trade and human rights regimes as they are, not as they ought to be. For example, where the WTO is concerned, there is an antideveloping country bias through tariff escalation, managed protection through anti-dumping, countervailing and safeguards regimes and continued protection in sensitive fields such as agriculture. At times, the major critique of the WTO is that it is failing in its mandate to prevent protectionism, particularly where that protectionism is applied against those industries where the least developed countries have a comparative advantage. This naturally integrates with political science analysis, which asks why the institution is captured in this way and how, if at all, this might be overcome.

We also need to be careful of using inappropriate generalizations in our analysis. For example, a useful study might look to the gains and losses from removing agricultural export subsidies as both WTO advocates and pro human rights NGOs decry agricultural protectionism. Yet while most presume that opening agricultural markets is of immediate benefit to developing countries, it is a fact that net food importing developing countries currently benefit from rich country export subsidies.

Economics might also query what are the implications of imposing human rights standards that cannot be met efficiently at current levels of development and which might have major opportunity costs vis à vis development itself. Thomas Cottier described this as 'the deepest conceptual flaw and irony of the international human rights system'. ${ }^{119}$ The converse argument, which is not mutually exclusive, is that imposing trade liberalization norms without the domestic infrastructure to allow just distributions, or even distributions that promote further efficiencies, could equally be flawed.

We might look at the missing infrastructure that arguably keeps too many in abject poverty. A related question is to ask what do both economics and philosophy say about efficiency reforms that are unlikely to be successful until such domestic infrastructure problems are fixed? Pranab Bardhan suggests that there may be disastrous results, as countries with better safety nets and means of responding domestically do better out of trade liberalization. ${ }^{120} \mathrm{We}$

\footnotetext{
119 Cottier, above n 21.

120 See Chapter 4
} 
have the work of scholars such as Amartya Sen ${ }^{121}$ arguing for certain minimum standards to allow for adequate development. In his seminal work, he argued for critical freedoms as a means to that end, namely freedom of political association and criticism; freedom to engage in market transactions; freedom from disease; freedom from disabling effects of inadequate education and literacy; freedom from extreme poverty. In his view these have both intrinsic and instrumental values.

This is just one example of how economics regularly considers the problems of short-term goals and long-term objectives, as Graciela Chichilnisky has dubbed them in her chapter. ${ }^{122}$ Her analysis of carbon markets raises a major example of a global risk management problem. While environmental NGOs sometimes say one cannot put a price on the environment, economists such as Chichilnisky have long pointed out that there are insufficient prices flowing from lack of property rights that cause overuse and degradation. Lack of well-defined property rights or enforcement leads to negative social cost externalities. Trade liberalization can exacerbate this but the first best solution is to address the property rights. Sometimes this is easy, for example, ensuring proper pricing of domestic inputs such as energy and water. The chapter by Chichilnisky explains the importance of property rights for environmental protection in the crucial field of climate control. Few would expect the WTO to directly seek to allocate property rights on a worldwide basis. Nevertheless, the lack of appropriate infrastructure in the poorest countries and the secondbest problems that this poses at least calls on analysts to re-evaluate the timing and importance of WTO reforms.

We should be concerned with these issues even if they are not the fault of the WTO, in circumstances where their absence would make WTO prescriptions sub-optimal, for example how important are property rights, or assistance programs to enhance capacity to utilize increased market access openings. If the first-best policy is not yet feasible, for example property rights, then some staged trade restriction might be a second-best interim solution otherwise the harm may be too costly.

\section{POLITICAL SCIENCE PERSPECTIVES}

A discussion of infrastructure and domestic mechanisms invites us to return our attention to the field of political science, although again the fields overlap and the views from one field are commonly dependent on conclusions from

122 See Chapter 13. 
the others. A range of scholars from other disciplines note the importance of infrastructure. The philosopher Thomas Nagel goes so far as to argue that there is inevitably a need to allow important structures to be developed illegitimately by unjust entities and then take them over for more justifiable purposes. ${ }^{123}$ As another example, if a major cause of poverty is the lack of institutional infrastructure as Rawls argues and Sen supports in part, then we might be looking to limit reforms to indirect mechanisms, such as promotion of the rule of law, democracy and efficient market infrastructure on the understanding that voters will call for redistribution in due course.

In addition to considering what the WTO and human rights regimes actually do, it is also desirable to consider their role and utility as international legal systems and remember that there are different theories of international law that would impact upon our analysis.

Because the greatest challenge facing international law is the problem of promoting compliance within a system without an effective enforcement process, a key aspect of any theory of international law is to consider why nations do or do not comply and how compliance can best be promoted. ${ }^{124}$ Such views vary from consent-based theories, which suggest that States face binding commitments in international law because of that consent, ${ }^{125}$ cooperative models as for example suggested by Chayes and Chayes, ${ }^{126}$ the legitimacy theory of Thomas Franck ${ }^{127}$ and a focus on the transnational legal process as suggested by Harold Koh. ${ }^{128}$ While these questions are aimed at the utility of international legal systems, the various theories are impacted upon by differing perspectives of political science. ${ }^{129}$ Any governance system,

123 Nagel, above n 66, 146.

124 Benedict Kingsbury, 'The Concept of Compliance as a Function of Competing Conceptions of International Law' (1998) 19 Michigan Journal of International Law 345.

125 Louis Henkin, How Nations Behave (Columbia University Press, New York, 1979).

126 A Chayes and A H Chayes, The New Sovereignty: Compliance with International Regulatory Agreements (Harvard University Press, Cambridge, 1995).

127 Thomas M Franck, Fairness in International Law and Institutions (Clarendon Press, Oxford, 1995); Thomas M Franck, 'Legitimacy in the International System' (1998) 83 American Journal of International Law 705; Andrew T Guzman, 'International Law: A Compliance Based Theory' (Public Law and Legal Theory Working Paper No 47, University of California at Berkeley, 2001); Martti Koskenniemi, 'Legal Cosmopolitanism: Tom Franck's Messianic World' (2003) New York University Journal of International Law and Policy 471.

128 Harold H Koh, 'Transnational Legal Process' (1994) 75 Nebraska Law Review 181; Harold H Koh, 'Why Do Nations Obey International Law?' (1997) 106 Yale Law Journal 2599.

129 See for example Kenneth W Abbott, 'International Relations Theory, 
whether the WTO or a national government, is merely a means to an end. At one extreme, a neo-realist perspective sees the application and pursuit of power as the essence of international relations, with legal institutions and rules having little impact on the behaviour of states. ${ }^{130}$ The contribution by Ken Shadlen looks at various theories of international relations and concludes that the neo-realist perspective does not explain some of the actual outcomes in the WTO system. ${ }^{131}$ Such a conclusion holds out hope for meaningful outcomes as a result of greater attention to the development of international legal rules and institutions. On the other hand this does not guarantee that the outcomes will be fair. Here, there are a range of critical legal perspectives that point to a range of fairness problems in current international law practice. ${ }^{132}$

The contribution by Andrew Lang brings a sociological element to the political science debate. ${ }^{133}$ Lang's contribution brings a constructivist perspective, looking at the role of the key players in defining the nature of the debate. Political theories that look at the role of individuals and complex organizations will consider the range of networks that apply. ${ }^{134}$ The contribution by Shervin Majlessi analyses the history of international trade law scholarship and situates it within the perspective of different international relations theories. In particular, he seeks to look at the implications of different theories, drawing on the works of other contributors to this volume. ${ }^{135}$

There are a number of other political perspectives with both theoretical and practical dimensions. A key aspect of politics is the lessons from political science as to the way organizations and vested interests work or don't work for optimal outcomes. Political science explains why we might seek institutions to promote certain outcomes in the face of inherent barriers. It helps us determine

International Law, and the Regime Governing Atrocities in International Conflicts' (1999) 93 American Journal of International Law 361; Anne-Marie Slaughter et al., 'International Law and International Relations Theory: A New Generation of Interdisciplinary Scholarship' (1998) 93 American Journal of International Law 367.

130 Hans J Morgenthau, Politics Among Nations: The Struggle for Power and Peace (Knopf, New York, 3rd edn, 1960); Stephen D Krasner, Sovereignty: Organised Hypocrisy (Princeton University Press, Princeton, 1999); Jack Goldsmith and Eric A Posner, The Limits of International Law (Oxford University Press, Oxford, 2005).

131 See Chapter 5.

132 David Kennedy, International Legal Structure (Nomos, Krakow, 1987); Martti Koskenniemi, From Apology to Utopia: the Structure of International Legal Argument (Cambridge University Press, Cambridge, 2005); H Charlesworth et al., 'Feminist Approaches to International Law' (1991) 85 American Journal of International Law 613.

133 See Chapter 7.

134 Examples include Anne-Marie Slaughter, A New World Order (Princeton University Press, Princeton, 2004); John Braithwaite and Peter Drahos, Global Business Regulation (Cambridge University Press, Cambridge, 2000).

135 See Chapter 14. 
when and why legal institutions may support these ends and how to optimize this. If every government was fully supportive of the economic theory of comparative advantage and supportive of the widest range of human rights, there would be little need for the institutions. While economists argue that unilateral trade liberalization is in a country's best interests, local vested interests opposed to efficient reforms mean that reciprocity is generally needed to sell the reforms politically. ${ }^{136}$ WTO obligations allow sensible governments to resist domestic protectionist pressures and still say they would have liked to help.

This does not mean that the mechanism selected by the WTO will be optimal. The WTO operates via a consensus mechanism. In theory even the smallest country can block any initiative by withholding its support. On the other hand, we would expect countries with significant economic power to use their influence to encourage uptake of such developments. Consensus has a range of costs and benefits as a decision-making mechanism. It seems fair to think that there was unanimous support for any key developments. On the other hand, requirements of unanimity lead us to expect that the system will be very slow to complete needed reforms. There is the overall question whether Rounds and reciprocity are a good way to improve rules requiring careful drafting as opposed to tariff reductions.

We might then ask whether reciprocity is sensible from a political science perspective even though it is poor from an economic perspective? On the one hand it allows the free trade lobby to counter protectionists, but it may do the opposite as well by ensuring we must 'get' something in return for adopting beneficial economic policies. Sauvé and Subramanian thus called it a peace treaty among mercantilists. ${ }^{137}$

Some analyse the debate from a sovereignty perspective. At the broadest level, what level of domestic political autonomy should be tolerated under an international trade treaty? ${ }^{138}$ This is a part of the challenge of global governance and determining the appropriate regulatory levels and the way they interact. A number of questions present themselves. Is there a crisis of legitimacy as some postulate? ${ }^{139}$ Can participatory rights flow from ICCPR? What

136 Nigel Grimwade, International Trade Policy: A Contemporary Analysis (Routledge, London 1996) 39.

137 Pierre Sauvé and Arvind Subramanian, 'Dark Clouds over Geneva? The Troubled Prospects of the Multilateral Trading System' in Pierre Sauvé et al. (eds) Efficiency, Equity, Legitimacy: The Multilateral Trading System at the Millennium (Brookings Institution Press, Washington DC, 2001) 19.

138 Michael H Trebilcock and Robert Howse, The Regulation of International Trade (Routledge, London, 3rd edn, 2005) 84.

139 Daniel Esty, 'The World Trade Organization's Legitimacy Crisis' (2002) 1 World Trade Review 7; Robert O Keohane and Joseph S Nye, Power and Interdependence (Addison Wesley Longman, New York, 3rd edn, 2001). 
is their actual content and how do we combine rights with effective governance, for example confidentiality and need to keep bargaining parameters from other countries? Is the WTO an unreasonable constraint on a sovereign's right to promote health, environment and labour rights? The traditional proWTO response is to say that Article XX and SPS constraints are examples of the exercise of sovereign power for mutual best interest. A sub-set of the sovereign rights issue is the entitlement to extra-territorial demands or at least impact as arose in Shrimp/Turtle.

Sarah Joseph in her chapter looks, inter alia, at the question of democratic deficit and its human rights implications. ${ }^{140}$ She notes concerns with entry into the WTO and performance under it. After noting various problems, including lack of public input and imbalance in bargaining power, she identifies various strategies for alleviating some of the problems, including technical support and transparency mechanisms. The role of transparency and monitoring systems to minimize the power of vested interests has been an issue upon which there has been some analysis of the WTO in the past. ${ }^{141}$ The Trade Policy Review Mechanism of the WTO and UNHR Committees are examples of transparency mechanisms that provide some promise. Trade negotiating committees at domestic levels, if appropriately established, might also help in part to overcome democratic deficit concerns. Another transparency device is an obligation to undertake human rights impact statements when key reforms are proposed. This is akin to the idea of a tax expenditure budget in tax policy.

Another governance issue is the question of linkage between the regimes and problems of fragmentation. Koskeniemmi notes the biases that are generated in a fragmented but interrelated set of international institutions. ${ }^{142}$ Linkage through the UN could overcome such biases, although that might be unworkable.

Political science can also give insights on specific sectoral issues and the way by which they may best be regulated. Bureaucrats, for example, who

140 See also Rahul Singh, 'The World Trade Organisation and Legitimacy: Evolving a Framework for Bridging the Democratic Deficit' (2008) 42:2 Journal of World Trade 347; Robert Dahl, 'Can International Organisations be Democratic? A Sceptic's View' in Ian Shapiro and Casiano Hacker-Cordon (eds) Democracies Edges (Cambridge University Press, Cambridge, 1999) 23; Albert O Hirschman, Exit, Voice and Loyalty: Responses to Decline in Firms, Organisations and States (Harvard University Press, Cambridge, 1970); Alois Stutzer and Bruno S Frey, 'Making International Organisations More Democratic' (2005) 1:3 Review of Law and Economics 305.

141 See for example Gabrielle Marceau and Peter N Pedersen, 'Is the WTO Open and Transparent?' (1999) 33 Journal of World Trade 5, discussing NGO criticisms and providing a partial defence.

142 Koskenniemi, above n 13. 
establish technical standards will naturally do so in conjunction with local industry, but such industry-vested interests might include protectionist criteria.

While changes could be made to the WTO's political processes, its current limitations need to be understood at the same time as consideration is given to the feasibility of any significant changes. This flows into the second key question we have posed, namely whether the WTO should do more to promote human rights. On this issue, many commentators from both sides of the spectrum have cautioned against such initiatives. Frieder Roessler argues that most linkage attempts are inefficient responses to policy differences. ${ }^{143}$ Better options are harmonization where possible and tariffs and subsidies otherwise. Linkage should be used to support domestic political coalitions among interest groups. Jose Alvarez argues against trade and human rights linkage because the latter is more in the nature of soft law, and incomplete and without universal consensus as to its key obligations. ${ }^{144}$ In a similar vein Dunoff argues that increasing legalization of other areas through WTO linkage may not be proper. ${ }^{145}$ Alston argued that the WTO is not set up to do justice to human rights concerns. ${ }^{146}$ In terms of the WTO and human rights interface, the WTO also does not have an optimal mechanism for debating non-trade norms. At best it carves out ambiguous exceptions.

The political perspective could also look at specific challenges in individual sectors. An example of the regulatory problems in the linkage field is the interface between trade and labour discussed in the chapter by Chantal Thomas. ${ }^{147}$ This field could cover working conditions, both in terms of hours and physical environment; exploitation of children; wage rates and acceptance of unionism. There are many difficulties in addressing these through the WTO or anywhere for that matter. Labour and environmental standards are not absolutes. There is no consensus as to the content of the right to unionize and collectively bargain. Many labour standards are of little relevance to the extreme poor, such as the rural self-employed. Economics suggests that diversity of labour standards is also a source of comparative advantage. Trade liberalization ought to be particularly beneficial to labour in developing countries because labour is the key factor of production. The interdisciplinary perspectives thus raise a range of challenging questions. If we were to ban child labour,

143 Frieder Roessler, 'Diverging Domestic Policies and Multilateral Trade Integration' in J Bhagwati and R E Hudec (eds) Fair Trade and Harmonization Vol 2: Legal Analysis (MIT Press, Cambridge, 1996) 21, 36-7.

144 Jose Alvarez, 'The WTO as Linkage Machine' (2002) 96 AJIL 146.

145 Jeffrey Dunoff, 'The WTO in Transition: of Constituents, Competence and Coherence' (2001) 33 George Washington International Law Review 979, 1012.

146 Philip Alston, 'International Trade as an Instrument for Positive Human Rights Policy’ (1982) 4 Human Rights Quarterly 155.

147 Chapter 10. 
by what criteria would we draw the line? How would we police the rule? What tolerance if any would there be for breaches? Will it hurt comparative advantage? Will it hurt the children and their families? Is this unimportant compared to the moral issue or the long-term economic positive externalities from education rather than work? Chantal Thomas's chapter analyses a range of legislative responses in the context of this field. She canvasses the possibility of providing broadly for positive obligations, the inclusion of general soft law principles, amendments or relying on existing style exceptions. She contrasts the lack of political will to deal with labour with the decision to include the TRIPS Agreement, of obvious benefit to leading developed economies. Overall she finds enough problems with the legislative option to seriously consider reliance on the judiciary as a preferred alternative.

There can be legitimate debate as to whether there are actual biases in negotiations, rule articulation, and adjudication. The latter might cover issues of who are to be panellists, what is their jurisdictional coverage and sources of law and how they should approach interpretation. The data is perhaps equivocal. Supporters of the status quo would point to the express precedence for Article XX options and the direct rights in SPS. The jurisprudence is more equivocal. An expansive interpretation of 'necessary' in Article XX GATT allowed wider scope for the exception as has the concern for the procedural manner of promulgation and execution rather than the substantive content, while a superimposed 'reasonable and least trade restrictive' chapeau interpretation goes the other way, albeit to a point where supporters might suggest there is a reasonable policy balance. That debate might depend on further dispute settlement issues such as burden and standard of proof and deference. An entitlement that looks balanced but which cannot be applied in that way is obviously problematic. Trade and labour is a key area where it would be questionable as to how to differentiate between protectionist and legitimate measures, particularly as political support would bring together both groups of supporters. Chantal Thomas has provided an analysis of the strengths and weaknesses of the adjudicatory record in aid of her moderate support for this tactical response to the problem. ${ }^{148}$

The chapter on culture by Hélène Ruiz-Fabri points to other regulatory issues including the question of culture as an economic value; the challenges as to soft law; short-term gains versus long-term costs; fragmentation concerns and the historical failure in having culture dealt with within the WTO. ${ }^{149}$

148 Chapter 10

149 See Chapter 8. See also Cécile Fabre and David Miller, 'Justice and Culture: Rawls, Sen, Nussbaum and O'Neill' (2003) 1:1 Political Studies Review 4. 


\section{CONCLUSION}

This chapter has sought to argue that the allied questions as to whether the WTO interferes with human rights and/or ought to do more to promote their attainment, requires complex interdisciplinary analysis. Too much of the debate to date has been polarized. Extreme positions can often be shown to be dependent on presumptions from other disciplines that are rarely supported within those fields. As has sought to be shown, economic theories depend in part on psychological predictions and philosophical perspectives as to resource distribution. Philosophical perspectives depend in part on attitudes to social interaction, appropriate political institutions and the relationship between sovereign states. Political perspectives in turn depend in part upon economic analyses as to the likely distributional outcomes in different political models and the philosophical perspectives alluded to above. Any attempt to properly answer the question as to whether the WTO unduly interferes with human rights and/or fails to do enough to promote them, must therefore involve a more nuanced and integrated approach to the analysis of past experiences in the context of these interdisciplinary insights. It is hoped that the interdisciplinary perspectives contained in this volume constitute a significant advance in that line of analysis. 